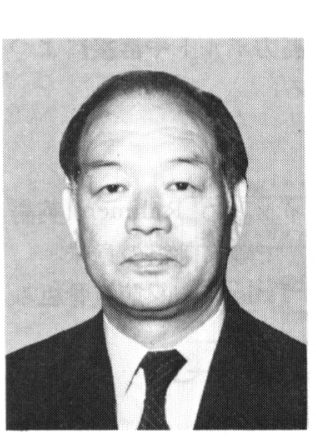

(C) 1985 ISIJ

\section{$\div \longdiv { 4 }$} 特別諥演

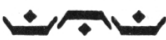

藤本盛 久*

\title{
Structural Steel and Steel Construction
}

\section{1. はじめに}

a ) 鉄の構造 · 前史 $\dagger$

1779 年, 中部 England, Coalbrookdale 近くの Severn 河上に史上最初の大鉄橋が建設された. 写真 1 に 示したこの橋は, 半円形のアーチ橋で, スパン $100 \mathrm{ft}$ $6 \mathrm{in,} \mathrm{ライズ} 45 \mathrm{ft}$ であり, 当時, コークス高炉を擁し, 世界最大のコールブルックデール製鉄所で製造された鋳 鉄が使用されている.鋳鉄を鋳てつくられた 5 本のアー チ肋材の断面は 12 in $\times 6 \frac{1}{2} 2$ in, 鉄材量は $378 \mathrm{t}$ である. 橋は 206 年を経た今日もなお使用に耐兄ているが，現在 は人道橋としてのみ使用されている.

この橋が完成した頃， 1784 年，Henry CoRT(1740 1800 年) が England の Portsmouth で反射炉を改良 して銑鉄を鍛鉄に精錬するパッドル (paddle) 法を発 明する. CORT は, この精錬法に合わせて, 従来の八 ンマーだけによる鍛造だけでなく, 1765 年に James WATT (1736〜1819 年) によつて改良された蒸気機関に $\dagger$ 文献 1), 2), 3), 4) より
Morihisa Fuјıмото

よる圧延と結合し板や棒を強力なロールの間を何回も通 して製造するパッドル・圧延法を確立する. 錬鉄 ( Wrought Iron) の誕生である.

1850 年代, 1860 年代までは, 鋳鉄による建築や橋梁 が引きつづき多かつたが，この頃になると錬鉄による建 造物も著しく増加してくる，錬鉄の時代である，1851 年に完成した Sir Joseph PAXtoN）1801～1865 年）によ

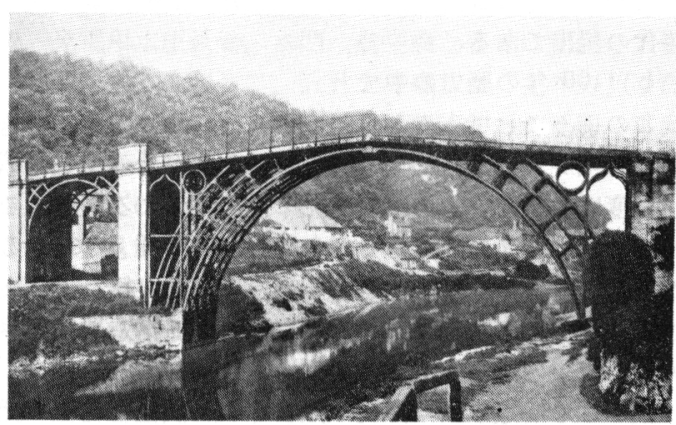

写真 1 Coalbrookdale の鋳鉄アーチ橋2)

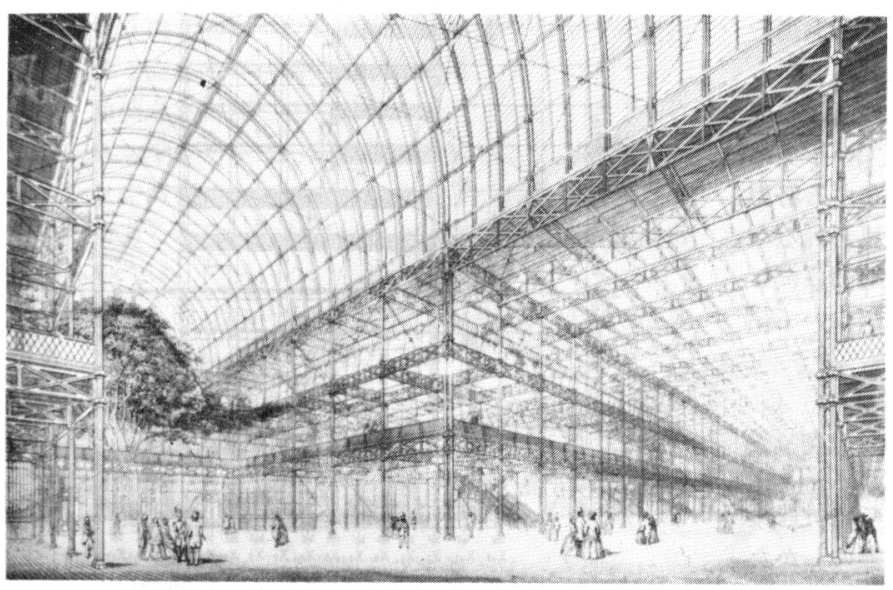

写真 2 Cristal Palaces), London, 1936 年焼失

昭和 59 年 10 月本会講演大会における浅田賞受賞記念特別講演 昭和 59 年 12 月 4 日受付 (Received Dec. 4, 1984)

* 東京工業大学名誉教授・神奈川大学工学部教授 工博 (Professor Emeritus of Tokyo Institute of Technology, Faculty of Engineering, Kanagawa University, 3-27-1 Rokkakubashi Kanagawa-ku Yokohama 221) 
る壮麗な鉄とガラスの建築 Cristal Palace(London) は 構造に鋳鉄と錬鉄が巧みに使われている(写真 2 ).

1889 年, Paris 万国博覧会に建てられた Alexandre Gustave Eiffel (1832 1923 年) による高さ $985 \mathrm{ft}$ の Eiffel 塔は $7300 \mathrm{t}$ の鍊鉄で組み立てられている.

この鍊鉄の時代は短い. 19 世紀後半に精錬法の画期 的な発明が相いつぐ. Henry BESSEMER (1813〜1898 年) の転炉法 (1856 年), Pierre MARTIN (1824 1915 年) による Siemens-Martin 法, すなわち平炉法 (1864年), また Sidney Gilchrist Thomas (1850〜1885 年) の塩基 性転炉など革命的な製鋼法の発明である.

19 世紀後半には, パッドル法でつくられた錬鉄に鋼 (Steel) がとつて代わり，これを処理する十分な能力の 圧延機の出現によつて, 長い間望まれていた大形の I ビ 一ムの生産も可能になる.イギリスの Dorman Long 社 は 1885 年にI ビームの生産を開始し, 1887 年に構造 用形材のカタログを発行している.19世紀末から20世 紀初頭にかけて鋼は市場を席巻し錬鉄は退場する. 鋼の 時代の現出である.

b) 100 年の歴史の中で

このよらにしてみると, 鉄による構造物の歴史は, 鋳 鉄の時代からみても約 200 年, 錬鉄や鋼からみても 130 年程度にすぎない。が国で見ても，鉄による構造物の 導入は明治維新以降であるから高々 100 年程度である が, 都心にそびえる超高層ビル群, 本四長大橋などはま さにこの 100 年間程に展開された鋼による構造技術の華 々しい成果の結晶である.

鋼による構造技術は, 更に, 多くの可能性を秘めて発 展してゆくことは間違いないことであろら。しかしなが ら，100 年の歴史を振り返つて見るとこの現在の技術は 一朝一夕にしてつくられたものではなく, 幾多の災害や 事故の経験の中から紆余曲折をへて到達したものである ことがわかるのであるが†2，このことは，この構造技術 が，将来にわたつて，顕在しあるいは潜在している多く の問題を内包しながら，それらを解決しょうとする努力 の中で進展してゆくことを示しているものと思われる.

本稿では，問題を建築鉄骨における鉄骨構造関係にし ぼり，鉄骨構造と構造用鋼材に関連した問題について紹 介する.

\section{2. 鉄骨構造とは}

「鉄骨構造 (Steel Construction または Steel Structure, Stahlbau)」といら用語は, 鋼橋に対して鉄骨建築 に用いられている骨組構造の名称であり, 定義のしかた にもよるが, よく使われる「鋼構造」は鉄骨構造, 鋼 橋, 容器構造などを含めた鋼を使用した構造の総称であ る.

鉄骨構造は, いうまでもなく, 鋼板, 山形鋼, $\mathrm{H}$ 形

$\dagger^{2}$ 例えば文献 30)，31），32）など参照されたい.
鋼，鋼管などの構造用の鋼材を高力ボルトや溶接によつ て骨組みに組み上げたものである。

a) 鉄骨,骨組の形

大別して,

ラーメン構造：ラーメンはドイツ語の Rahmen, 英語 では Rigid Jointed Framwork で剛節骨組の意味.

トラス構造：トラスは英語の Truss, ピン節点骨組み の意味.

がある。

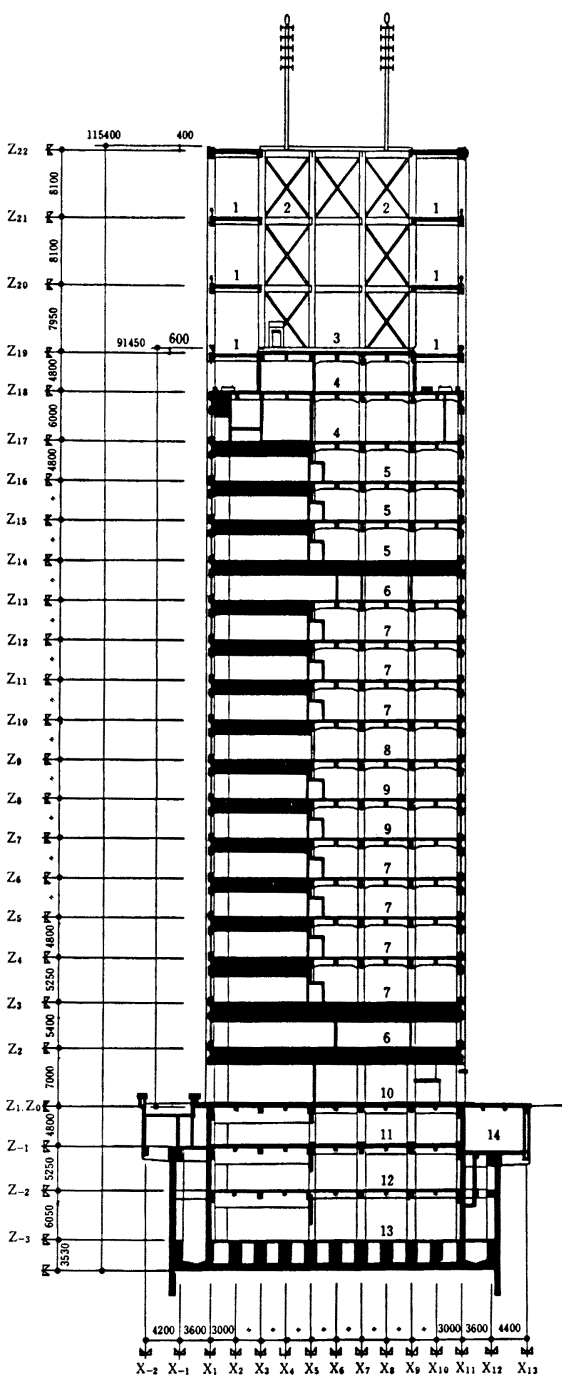

1 アンテナデッキ 2 クーリングタワー 3 設備機械字. 4 設備機械空 5 無線機珹㸃 6 事務空 7 デー夕通信 機械室 8 設備機械室・食堂 9 電力室 10 エントラン スホール 11 駐車場 12 電力察 13 特高受電宾 14 コンベアー式駐車場

図1 中野電々ビル(ラーメン構造) 6) 地下 3 階, 地上 18 階, 塔屋 1 階, アンテナデッキ 3 凰 軒高 $91.45 \mathrm{~m}$, 最高高さ $115.40 \mathrm{~m}$ 


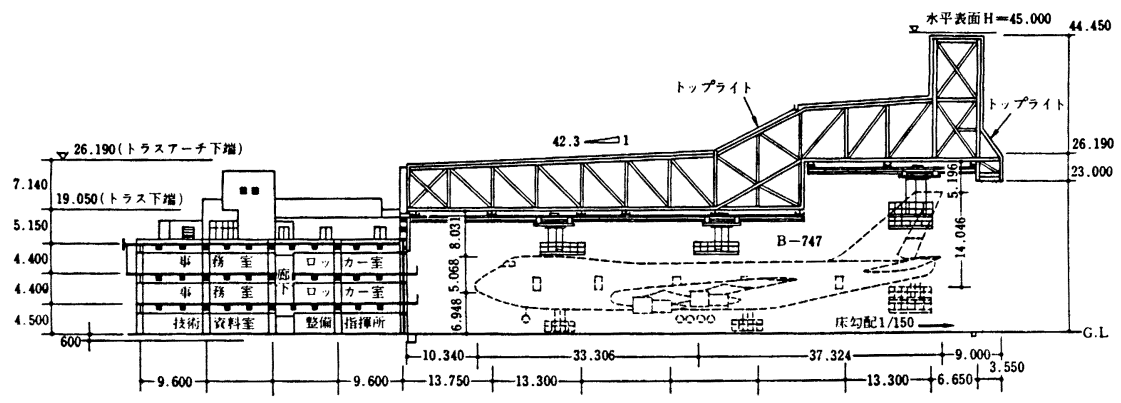

汹2 日本航空成田第 1 ハンガー(トラス構造 $\left.)^{7}\right)$ 間口×奥行 $190 \mathrm{~m} \times 90 \mathrm{~m}$ 高さ $44.450 \mathrm{~m}$

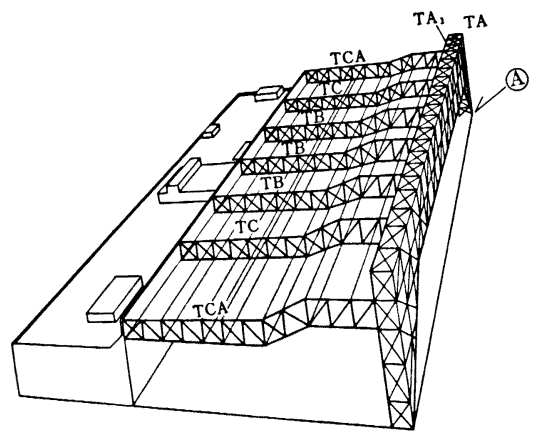

略 3 日本航空成田第 1 ハンガーの構造システム7)

図1にラーメン構造, 図 2 にトラス構造の例を示し た. 鉄骨建築の空間は, これらのラーメンやトラスをな らべそれらを相互につなぎあわせて構成されている。図 3 は図 2 に示したトラス構造の全体構造システムであ る.また最近の大空間構造として, 吊屋根構造とか, 鉄 骨部材を 3 次元的につないで自由な平面や曲面の大屋根 を構成する立体トラス構造などもある。

b ) 重要な接合部

ラーメンやトラスは，山形鋼，H形鋼などの鋼材を高 力ボルトや溶接によつて相互につなぎあわせて組み立て るものであるから，つなぎめすなわり接合部の構造は重 要である。

図 4 に接合部設計の一例を示した。建物が，自重や積載 重量, 地震力, 風圧力, 積雪などの外力をうけた時, こ の部分には複雑な応力や歪みが生ずるが，それに対処し て慎重に設計されている.

\section{3. 建築物と構造上の安全}

一般に建築物が生活の空間として満たすべき要件は, 意匠·平面・立面・構造・環境設備などに関連して多岐 にわたつている。また,このような造形上, 居住性上, 技術上の問題だけでなく，経済性を満足することも重要 な条件である.

こ机らのらち構造上の荘件は他と比べてかなり技術的
な面が強い，建築構造は前項でもふれたように，常時の 自分自身の重さや積載物の重量に対して安全であるばか りでなく，いつ作用するかはつきりしていない，地震， 強風, 豪雪などの作用に対してまた十分安全でなければ ならないのである。

建築物と同じような構造物である橋梁, 船舶, 圧力容 器, 発電用水圧鉄管, 水門, 航空機などでは完成して使 用状態に入ると同時に, 設計上考慮した「主外力」の洗 礼を受けることになるが，構造に久陥があれば即，重大 な事故につながるといらこともあつて(図 5 ), 設計，施 エに際しては，慎重な配慮がなされるとともに，「適正 な価格」も維持されている.

これに対して建築物の場合は，建物が完成してから常 時の使用状態では, 自重や積載荷重に対して安全に空間 が確保されていればよいのである。建築物として構造的 な真価が問われているのは，50 年に 1 度，100 年に 1 度とかのしかもいつくるかわからない, あるいは構造の 寿命の間にはこないかも知れない地震, 強風, 豪雪など の洗礼を受けた時なのである。

鉄骨建築，特に中小規模の鉄骨建築の安全性について 最近なんとなく不信感のあることが取り沙汰されること が多いが, 建築物の場合, 構造上の最終的な安全を決定 する「主外力」が他の構造とは本質的に異なるところ に，設計，施工に際しての「甘さ」，「油断」があるよう である。

\section{4. 設計，施工の技術レベル}

わが国の鉄骨構造が設計され施工される技術レベル は, 国際的にも一流である超高層ビルのレベルを頂点 に, 中小規模の建築物のレベルまで富土山型に裙野がひ ろがつている. 問題は, 鉄骨構造の着工面積や棟数から 言つて大部分の $80 \%$ 以上が，この裾野のレベルで設計 され施工されているといら実態にあるのである.

特に, 鉄骨加工業者は, 全国で 2 万社とか 3 万社以上 であると言われているが，最近，(社)鋼材俱楽部が(社) 全国鉄構工業連合会と鉄工建設業協会の協力によつて, 調査した結果，次のような実態が報告されている. 




(b) 正面

(c) 側 面

図 4 日本航空成田第 1 ハンガーの柱脚詳細(図 3 の A 部) ${ }^{7)}$

（1）鉄骨加工専業はわずか $12 \%$, 建築金物業 $8 \%$, 鉄骨々建築金物業の兼業 $42 \%$ ，鉄骨々その他業 種（建 設業，建材業など）との兼業 $21 \%$.

（2）加工内容は，小規模鉄骨（階数 $1 \sim 2$ 階で加工 トン数 $20 \mathrm{t}$ 末満) $41 \%$, 手すり，階段，㒛など $22 \%$, 合計 $63 \%$ で小物がかなり多い。

(3) 従業員数 10 人以下で月間加工能力 $50 \mathrm{t}$ 以下 の企業が $76 \%$ をしめる.

（4）建設業法による登録業者 $65 \%$.

（5）鉄骨加工関連団体加入 $35 \%$ ，未加入 $55 \%$ ，解 答なしを含めると $65 \%$ が未組織.

（6）未組織の業者で団体加入の意志をもつものは $25 \%$.

昭和 59 年度における建築鉄骨（鉄骨造と鉄骨鉄能 ב ンクリート造の鉄骨) に使用される鋼材量は, 日本鋼構 造協会経済委員会の推定によると約 700 万 $\mathrm{t}$ である ${ }^{9}$. このらち組織化された鉄骨建設業協会（鉄骨加工業者大 手を中心とした組織, 約 70 社）と, 全国鉄構工業連合
会（中小の鉄骨加工業者で組織，約 3000 社）で 400 500 万 $\mathrm{t}$ 程度加工されるが, 残りはほとんどが前述のレ ベルで製作加工されることになる，設備的に見ると，わ が国鉄骨加工業者の加工能力は 1000 万 $\mathrm{t}$ 以上であると 言われているから，その受注に際しては，不況の中での 経済原則に従つた熾烈な競争が行われ，適正な価格の維 持, ひいては適正な品質の確保にもいろいろと問題が多 い.

\section{5. 適正価格の維持}

経済原則に従えば，需給の関係が価格に大きな影響を 与えることになるのであるが，前項でのべた業界の構造 も反映して適正価格の維持は実際にはなかなかむずかし い状洗にあるようである。需要が低迷すると，会社が生 きのこるために，やむなく赤字覚悟で受注するようなこ とになる．このような状況の中で，鉄骨の市場価格は， その品質や加工業者の技術レベルに関係なく決定される ことが多い。 


\section{LESSONS OF FAILURES}

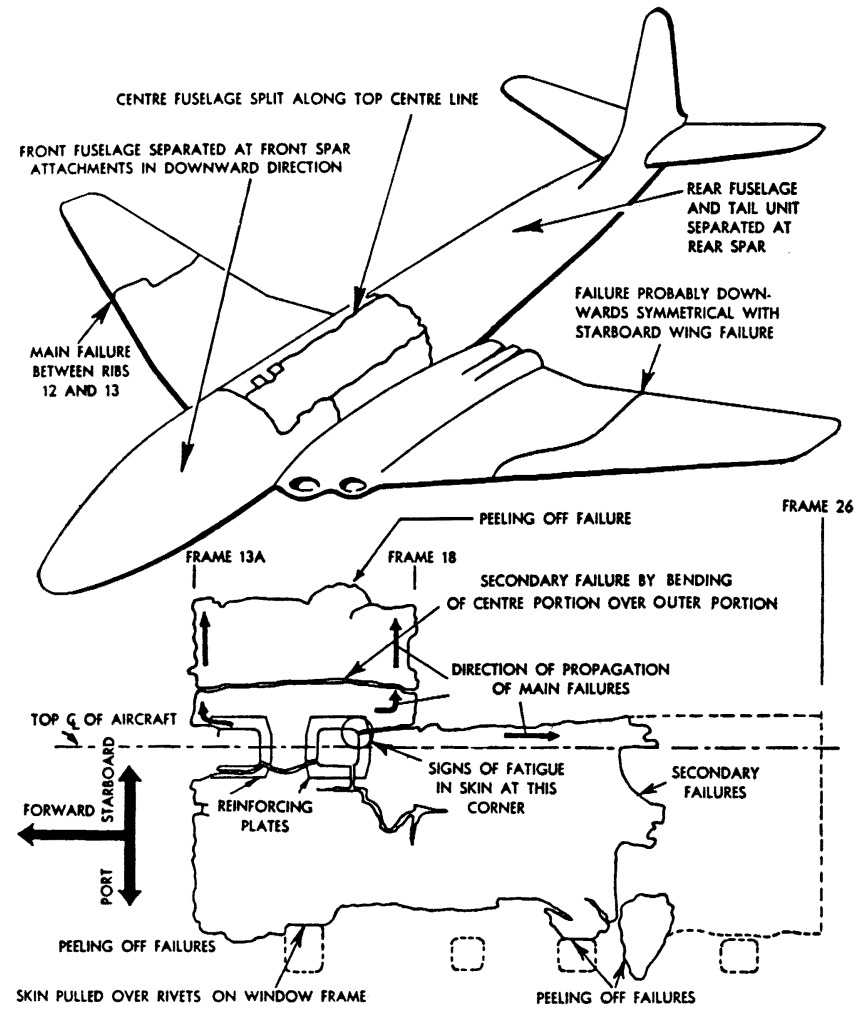

BOAC は 1952 年初頭から世界にさきがけてジェット旅 客機 De Havilland Comet 機を就航させたが、1953 年 4 月, 1954 年 1 月, さらに 1954 年 4 月の三回にわたつて, 飛行中原因不明の 警落をし，多数の乗客の生命がうばわれ た. その後の調査により, 原因は客室を常飞地上と同気压 に保つための余圧による繰返負荷の効果によつて機体が疲 労破壊したためであるとされている。

四 5 コメット機の機体の破壊状沉 ${ }^{8)}$
鉄骨建設業協会で実施している鉄骨生産工場の認定制 度では工場を以下に示すイメージで 4 種類に類別してい る.な扎文中の JASS 6 は日本建築学会制定の「鉄骨 工事標準仕様書」である.

$\mathrm{S}$ 類: 超大型, 特殊工事の実績があり, 新材料・新工 法にも対処できる能力を有している.

品質管理に十分な体制と能力を有しすべての鋼種, 板 厚のものが適正に取り扱える態勢を整えている.

月産 $1200 \mathrm{t}$ 程度以上

HA類 : 15 階建程度以下の鉄骨は, JASS6 に示され るレベルの品質のものを自主的に製作できる態勢を整え ている.

50 キロ級以下の鋼材で板厚 $50 \mathrm{~mm}$ 以下のものを適正 に取り扱らことができる態勢を整えている.

月産 $800 \mathrm{t}$ 程度

MB 類 : 9 階建程度以下の鉄骨は, JASS6 に示され るレベルの品質のものを自主的に製作できる態勢を整え ている.

41 キ口級鋼材では板厚 $32 \mathrm{~mm}$ 以下， 50 キロ級鋼材 では $25 \mathrm{~mm}$ 以下のものを適正に取り扱らことができる 態勢を整えている.

月産 $250 \mathrm{t}$ 程度
$\mathrm{RC}$ 類： 3 階建以下の一般的な鉄骨を完備した設計図 書に沿い, JASS6 に示されるレベルの品質のものを製 作することができる態勢を整えている.

50 キロ級以下の鋼材で板厚 $16 \mathrm{~mm}$ 以下のものを適正 に取り扱らことができる態勢を整えている.

月産 $100 \mathrm{t}$ 程度

同協会の調査によると，価格の決定に大きな比重をし める直間比（直接工の労務費に対する間接工や職員の労 務費, その他の間接経費などの比）は，各類工場でばら つきはあるが平均值で約 $\mathrm{S}$ 類工場 $210 \%, \mathrm{HA}$ 類工 場 $200 \%$, MB 類工場 $110 \%$

であり， RG 類や，前記の未組織の中小工場などでは この比は更に小さい值であることは容易に想像される.

したがつて上述のように，鉄骨の市場価格が，その品質 や加工業者の技術レベルに関係なく決定されているとす れば，品質管理体制を整え，技術向上につとめている工 場ほど競争力は弱くなり，更には，これによる弱体化を ふせぐために数段階の下請製作が行われ, 結果として品 質性能が十分でない鉄骨になりかねないことになる。

最近の話題である10)11) 韓国やブラジルからの輸入鋼材 問題, 韓国での加工問題, SM 材と SS 材の取りちがえ 問題などなど，根はすべて価格問題であろう. 


\section{6. 再び構造上の安全について}

建築物は 3 項でのべたように，何時襲つてくるかわか らない地震の作用や，また強風や積雪の作用に対して構 造全体ならびに構造の各部が十分な強度をもつことが必 要である.

現行の設計法は, これらの想定された外力に対して構 造の各部に生ずる応力度が, 計算上, 構成構造材料の許 容された弾性範囲内にあることを条件とした弾性設計法 である．外力のらち風圧力や積雪の作用については，実 際の状況も，ほぽこの設計法が成り立つものと考えられ るが，地震の作用に対しては，強震，烈震レベル以上の 大地震については, 構造の各部の応力度は弾性範囲を超 えて塑性範囲で激しい繰り返し力をらけることが，十勝 沖地震, 宮城県沖地震, 日本海中部地震等で実証されて いる.

すなわり，構造各部が，弾塑性の範用での繰り返し力 に対して，十分な強度と破壊にいたるまでの変形能力を 有することが必要になる。この際構造各部の中で最も問 題になるのは，接合部である．溶接部分を多く含むこの 接合部が，地震の作用をうけた場合，どの程度のひずみ レベルで繰り返し力をらけるのか. 地震の波そのものに も明確にされない問題の多いことなどから，その推定は かなりむずかしいことではあるが，最近少しずつ明らか になつてきているので，柱・はり接合部を例にとつて考 えてみよう.

a）大きい地震時のひずみ

図 6 に示した柱・はり接合部のはり上フランジ端部に おけるひずみ分布は，一般にaのよらな分布形をしてい るのであるが，ひずみが塑性に入ると，bのようにこの 形が逆転することがある1213). したがつて，この場合平 均ひずみ度をとることとし，この部分の平均ひずみ度を $\varepsilon$, 鋼材の降伏点におけるひずみ度を $\varepsilon_{y}$ とすると, 通常
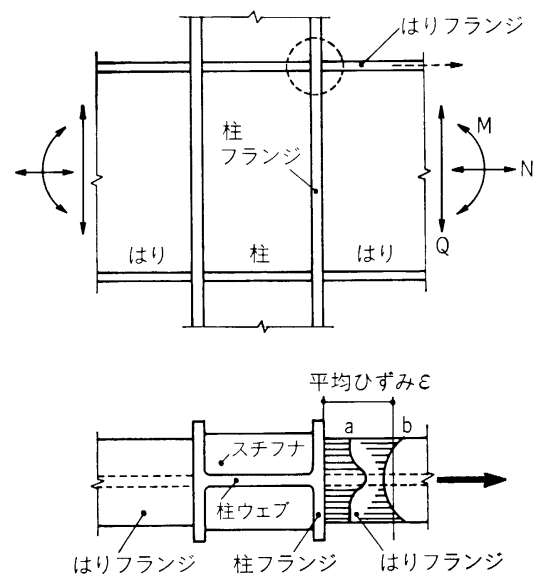

図 6 柱はり接合部のひずみ
のビルディングフレームの場合に対して，地震時のひず みレベルとしては, 最近の研究によると

$$
\varepsilon / \varepsilon_{y}=4 \sim 12^{14)} \quad \varepsilon \leqq 1.8 \% \%^{15)}
$$

であるといわれている。すなわち，一般のビルディング フレームは地震の作用をら计た時, 図6に示した接合部 の柱フランジにはりフランジが取り付く近傍では，ほぼ $\varepsilon=4 \varepsilon_{y} \sim 12 \varepsilon_{y}$ ，または最大で $1.8 \%$ 程度のひずみレベル


用いられる 41 キロクラス, 50 キロクラスの鋼材の場 合 $0.1 \% \sim 0.15 \%$ 程度である).

このひずみの分布をある 1 例について，より詳細にな がめてみると，図7（b)に示したエンドタブ（図13参

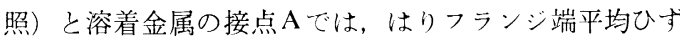
み度の約 3 倍程度，（c）の裏あて金（図13 参照）の取 り付けのための寸多肉溶接のB点では，同じくはりフラ ンジ端平均ひずみ度の約 6 倍程度のひずみ集中を生じて いる16)

このよらに接合部で鋼材や溶接部に要求されるひずみ レベルは相当に高く，しかも繰り返し力の状態であるこ とを考学ると，かなりきびしい要求性能であることが理 解できよう。

b ) 柱フランジ板 Z 方向の力学的性質

一般に，外力をらけた鉄骨構造接合部の心力・ひずみ の分布状態は極めて複雑な様相を呈するが，最近，超高 層ビルディングフレームの柱・はり接合部の安全性につ いて，図 8 に示したa）項でのべたようなはりフランジ
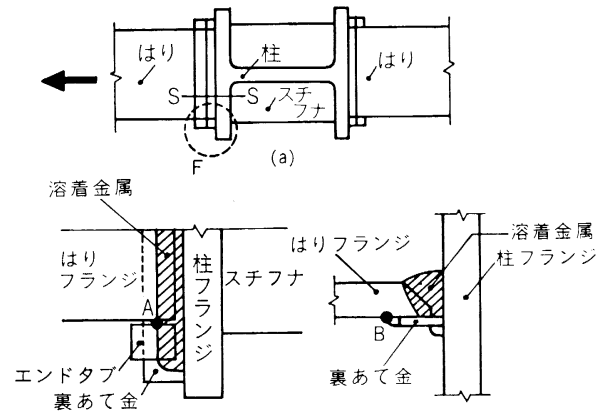

(b) F 部詳細

(c) S-S断面

図7 ひずみ集中
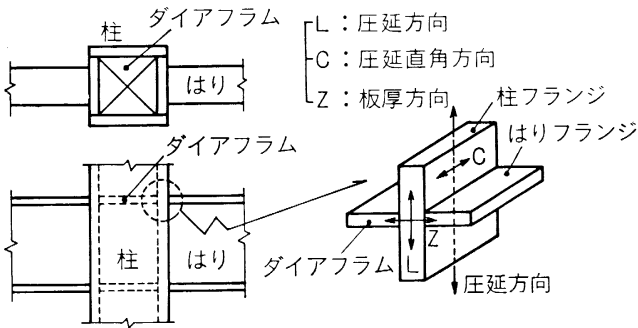

図 8 柱フランジ板 


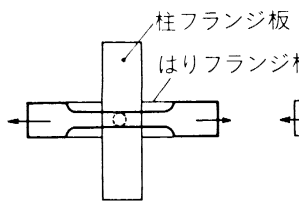

(a) 引張試験 $H_{1}^{\prime}$ 应 9

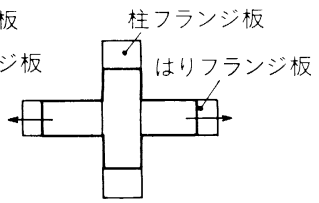

（b）十字型引張武験片

向引張試験片
端から高いひずみレベルで繰り返し力の作用をらける柱 フランジ（一般に，SM50 材で厚さ $30 \mathrm{~mm} \sim 70 \mathrm{~mm}$ 程 度の場合が多い) のZ方向の引張性質が問題となつてき ている.

これは，箱形断面柱の柱・はり接合部グイアフラム (図 8 参照) の取付けに多用されているェレクトロスラ グ溶接の溶込み幅の測定に，超音波探傷法による垂㨁探 傷が行われるよらになり ${ }^{17)}$, 鋼材自体のラミネーション (lamination), 偏析, 各種の介在物 (inclusion) などの 欠陥が，溶接部の欠陷と同時に探傷されてくるという背 景が，その理由になつているよらである。しかしながら もともとこの問題は, 昭和 30 年に仲威雄博士 ${ }^{18)}$ が, 圧 延鋼板の異方性として溶接構造の構造設計上の注意を換 起されてからの問題なのであるが，一方，上記の理由の ほかに数年前より，連続鋳造法により製造された鋼板が 多用されるようになり，従来の鋼塊より圧延された鋼板 と, 特に偏析や介在物などの点で若干様子が異なるとい らよらなことも背景にはあるようである。 また，特に最 近問題になつている溶接部直下で鋼板の表面と平行に伝 ぱしていく階段状の割れ（ラメラティア）点）もこのよら な鋼材の層状組織に関係した問題であるとされている.

このような, 鋼板のZ方向の性質については, よく知 られているょらに，L方向， C方向に比べて衝撃值は小 さく, また図 9 ( a ) のような引張試験片の場合は, しば しば引張強さ，伸びなどがあまりでない傾向がある．実 際の状況に近い図 9 (b) のよらな十字形の引張試験片で は, ひずみが広く分布することもあつて引張試験の結果 ではL方向，C方向に比べてあまり差のないことが確か められている19).

しかしながらここの部分の鋼板の層状組織として， ラ ミネーション, 非金属介在物としての酸化物 $\left(\mathrm{Al}_{2} \mathrm{O}_{3}\right.$ な ぞ）・硫化物・けい酸塩など, C, Si, Mn, P, S などの 偏析, また水素の存在等々が Z 方向の機械的性質にどの ような影響を与えるのか.この部分のひずみ度は, 最近 の研究によれば19)，a）項でのべたはり端ひずみ度の 60\% 程度であることが確かめられているが，なお相当 のひずみレベルで繰り返し力をらける部分でもあり，ま た実際の構造物では複雑な多軸応力状態下にあること, 溶接による影響などとも考え併せて，脆性的な破壊を生 ずるおそれもあり 24) 26)，早急に，鋼材の製造上はもち ろん, 設計面においても検討がなされなければならない

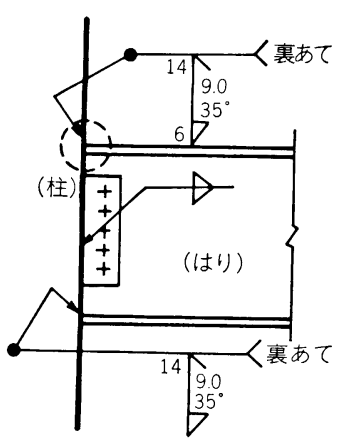

はり $\cdot \mathrm{H}-500 \times 200 \times 10 \times 16$

図10 柱・はり接合部のディテール

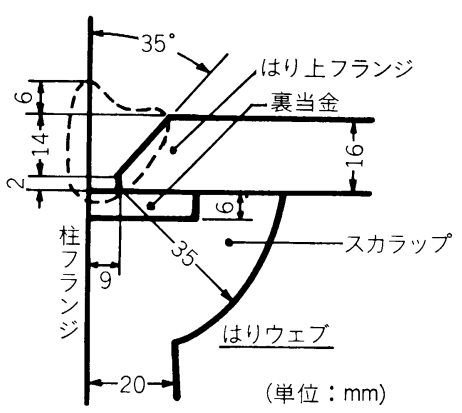

四11はりフランジとスカラップ (四12の上フランジの詳細)

と思う。

c）柱・はり接合部のディテール

以上のよらな構造上要求される性能を十分発揮できる よらにするため, 力の流れと伝達を考慮して, 各部のデ ィテールが設定され加工が行われることになる.

具体的例で，このことを考えてみよう.

図 10 は, ビルディングフレームの柱・はり接合部で 通常採用されている現場溶接によるはり端のディテール を示したものであるが29)，このディテールは，はり端に 生ずる曲げモーメント，せん断力などの応力を柱に完全 に伝達するため，溶接と高力ボルトの原則にしたがつて 設定されている．はり上下のフランジをつき合わせ溶接 により全強を柱フランジに伝えており，そのためつき合 わせ溶接としての曖昧さをのぞくため, フィレット部を 欠いてスカラップを設け（図 11），完全とけ込みのつき 合わせ溶接としている．せん断力はウェブ面に配置され た高力ボルトによつて伝達されている．はり端の応力を 完全に柱に伝達させるといら構造設計上の性能を満足す るためには，このようなディテールが必要になることに なる。

d) 加工

更にこの部分の製作加工を考えてみると，上下フラン ジの開先加工を含めて, かなりの手数が必要であり, 加 


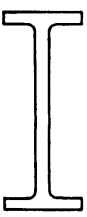

(1)

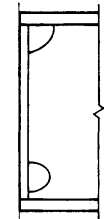

け書き



(2) スカラッフ 切断

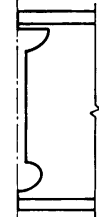

(3) ウェプ

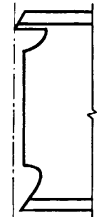

(4)

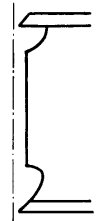

(5) 上フランジ

困 12 はり端 $(\mathrm{H}$ 形鋼)の加工順序

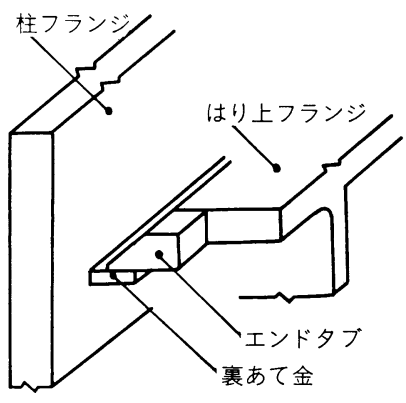

四13 エンドタブと裏あて金

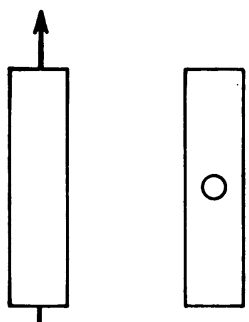

(b)



(c)

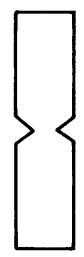

(d)

図14 不連続断面

工用の機器も十分整備されていないと精度のよい加工は できないことになる．図 12 は，この部分の加工で，通 常とられている加工の順序を示したものであるが，かな り面倒な作業であることが理解できよう．はり端の加工 後, 現場での溶接作業は, ウェブの高力ボルトの締付け 完了後行われるが，建て入れの精度によつては，完全な 溶接が期待できないので，溶接による収縮なども考虑し た上で，溶接開先関係の諸寸法が許容差内におさまるよ ら，十分な精度で建て入れが行われなければならない。

溶接作業は, 周辺機器の整備と足場の確保なぞ, 溶接 上のいろいろな条件をととのえた上で行うことになる が，完全なつき合わせ溶接が行われるために，裏あて 金，エンドタブが取りつけられる（図 13）．溶接完了 後エンドタブは原則として切り打とすことになつてい る.

溶接作業が終了すると, 必要に応じて, 溶接部の外観 検査，超音波探傷検查などによつて欠陌の有無を検出 し，補修が行われる。

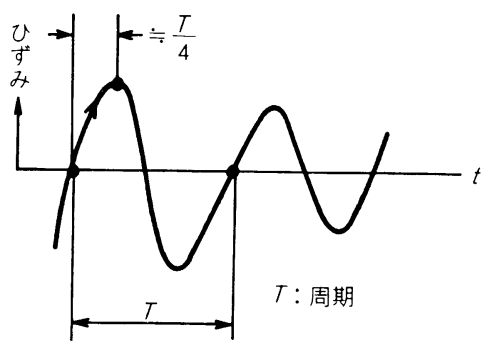

図 15 地震時のひずみ速度

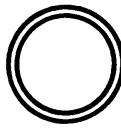

鋼管

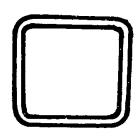

角鋼管
図16 塑性加工された鋼材

以上，具体的な一例で，構造設計上の要求性能を満足 させるための作業を簡単にのべてみたが，精度の高い加 工と建方，慎重な溶接作業と検査によつて始めて品質が 確保されることになる。

\section{7. 断面の不連続, ひずみ速度, 降伏比, 蒀性加工 ${ }^{24)}$}

図 14 に示したような各試験片に引張力を加えて破断 させた場合の伸びは，（a )に比べて（b)，（c），(d)の ように断面に不連続のある場合は，著しく小さくなるこ とはよく知られている。 また，この伸びは，鋼材の

[降伏比 $]=($ 降伏点 $) /($ 引張強さ $)$

によつても大きくことなり，断面に例えば(b)のように 円孔のある場合で，降伏比が 0.8 程度になると，降伏比 が 0.65 の場合に比べて伸びが $1 / 2 \sim 1 / 3$ 程度になるこ とも報告されている.

図 15 は, 地震の作用をらけて構造物が振動している ときの，ひずみの時間的変化を抽象的に示したものであ る.

例えば，比較的規模の小さい筋違つきの鉄骨構造であ ると, その固有周期が $0.25 \mathrm{~s}$ 程度のものが多いが，地 震時にもこの程度の周期で振動しているものとみると, 構造のある部分は, ひずみ 0 の状態からひずみの最大值 に達するまでの時間が， 


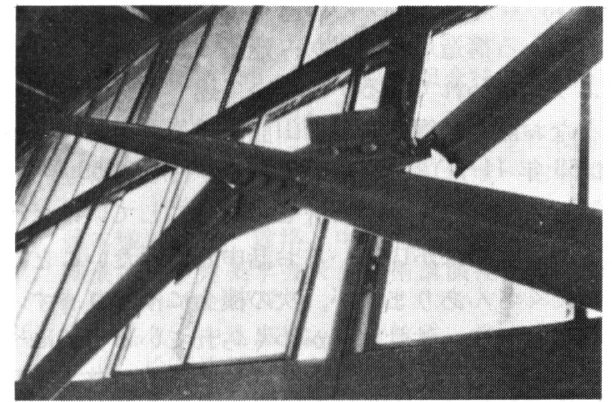

写真 31968 年十勝沖地震における八戸高専体育 館筋違 $(1 \mathrm{~L}-75 \times 75 \times 6)$ の脆性破断 $\left.{ }^{20}\right)$

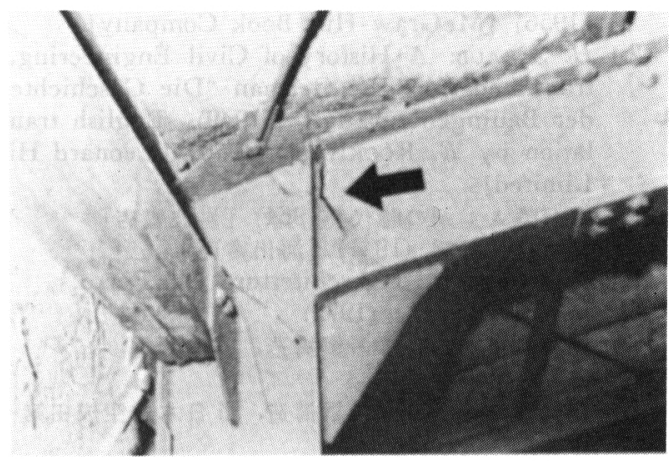

写真 4 1978年宮城県沖地震による仙台市 $\mathrm{S}$ 運輸倉 庫山形ラーメン隅角部の脆性き裂20)

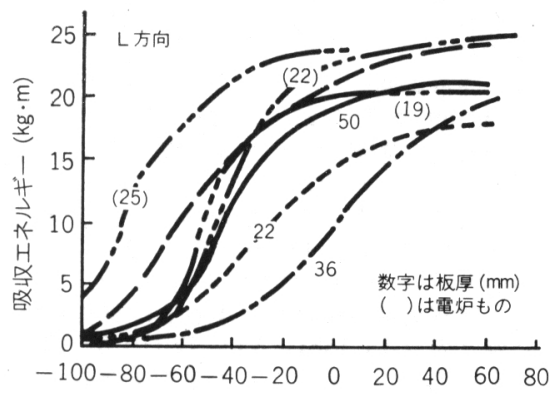

$\left({ }^{\circ} \mathrm{C}\right)$

図17 圧延 $(\mathrm{L})$ 方向吸收エネルギー

$$
T / 4=0.25 / 4=1 / 16(\mathrm{~s})
$$

になる.この程度のひずみ速度でも，特に断面に不連続 のあるような場合には，伸び能力に影響があり，切り欠 きなどの存在とあいまつて，脆性的な破断を示すことが ありらるようである。これは, 試験機などの関係で明確 にはまだ実験的に再現されてはいないが，最近の地震に よる被害建物のうち，体育館などの筋違付構造における 山形鋼筋違材端接合部（ボルト穴存在）に生じている脆 性的破断で明確に示されている(写真 3 , 写真 4 )。
図 16 は最近ビルディングフレームの柱として用いら れている鋼管，角形鋼管である。これらはいずれも材質 が塑性加工の影響を受けてお特り，原板に比べて機械的性 質が異なつている. 降伏点の上昇, 伸びの減少である. 特に角形鋼管の隅部は加工度が著しいが，この部分も含 めて上述の板厚方向の引張りに対して十分注意する必要 がある。

\section{8. 電炉ものと高炉もの ${ }^{33) 34}$}

図 17〜19 は，最近，私の研究室で行つた実験で 50 キロクラス鋼材の高炉もの之電炉ものの吸収エネルギー を示したものである.

これによると，L方向については，電炉もののほうが

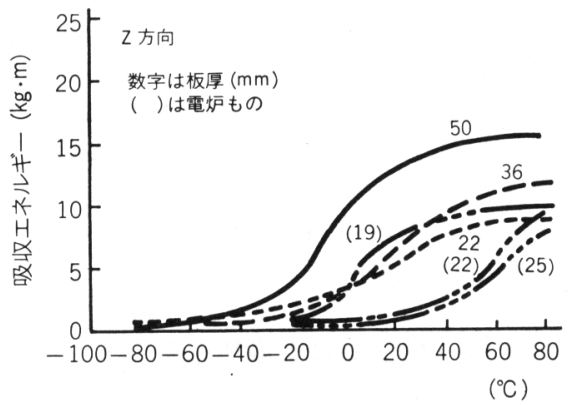

図 18 板厚 $(\mathrm{Z})$ 方向吸収エネルギー



図1922 mm 厚板の吸収エネルギー

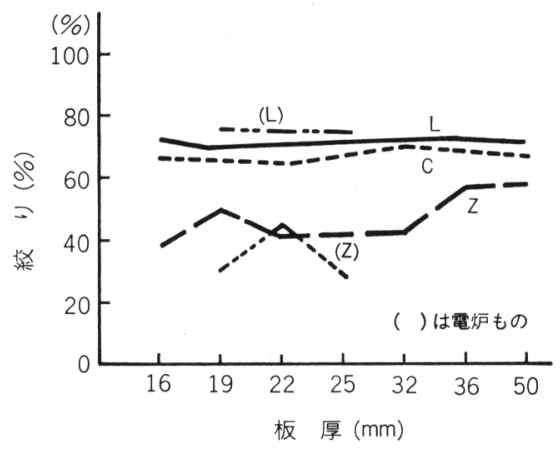

図20 絞可 
高い数值を示していること, $\mathrm{Z}$ 方向では電炉ものの值は 低く，特に板厚 $20 \mathrm{~mm}$ を境にして劣化していることな ど注目される。図20は絞り值であるが, 吸収ェネルギ 一と，かなり相関があるようである。

この上らな高炉ものと電炉ものとの差異は, 化学成分 で電炉ものは $\mathrm{Cu}, \mathrm{Cr}, \mathrm{Ni}$, ならびに $\mathrm{N}$ 量が多いこと, 圧延時の減面比が小さいこと, 高炉ものは制御圧延の技 術が進んでいることなどがあげられている.

また，このような電炬ものについての性状は，建築の 分野で多量に使用されている鉄筋コンクリート構造用の 異形棒鋼についても同じであるようである2728)．棒鋼の 場合は継手にガス圧接が用いられるといらことから，鋼 材の溶接性とは別の観点からの注意が必要であ万ら.

電炉もの鋼材の吸収エネルギーの低いことが，構造強 度上，特に柱はり接合部の強度にどのような影響がある かはあまり明確ではないが，柱フランジ部のような板厚 (Z) 方向に力をらける部分の使用については，6 項での べた程度のひずみを生ずることから考えて特に注意が必 要であろう.

電炉もの特に $20 \mathrm{~mm}$ 以上の厚ものについての改善の 努力を期待申し上げたい．

\section{9. 再び品質と価格について}

以上いろいろとのべてきたよらに，想定された各種の 外力に対して安全でなければならないといら構造設計上 の要求性能を満足する品質を確保するためには, 所要の 機器を備光，十分な技術レベルを有している工場によつ て製作・加工，建方が行われなければならないのであ る. その点，わが国の鉄骨加工業界の実情は，必ずしも 十分ではないと言える、鉄骨加工業で組織化されている 範囲は，鉄骨建設業協会，全国鉄構工業連合会傘下の約 3100 社で全国で数万社といわれる中小の工場について は全く野ばなしの状況である。この業界の技術レベルの 向上や，資格の設定などに対して強力な対策が必要であ る.

また，要求された品質を確保するためには，当然，適 正な価格と無理のない工期が必要である．特に鋼材の価 格子含めた価格に対しては，需給の関係や業界内の競争 など，経済の原則にしたがつているのだ，といつてしま えばそれまでであるが，低い価格では，高い品質など期 待できないのは当然であり, 適正な価格の維持と無理の ない工期の確保に拔本的で強力な方策がとられなければ ならない。

\section{0.おわりに}

今回，はからずも日本鉄鋼協会の「浅田賞」をいただ く栄に浴し, 昭和 59 年 10 月 9 日, 広島大学で行われ た表彰式につづいて受賞記念の講演をさせていただきま した.
本稿は，鉄鋼協会関係の皆さんが日頃苦心してお作り になつている構造用の鋼材が，建築の鉄骨構造の分野で どのよらに使われているかについて述べたものです，同 じようなお話を鉄鋼協会の西山記念技術講座第 56 回 ${ }^{22}$ (昭和 53 年 11 月), 第 98 回.99 回 ${ }^{23)}$ (昭和 59 年 5 月) でお話ししておりますので併せて参考にしていただけれ ば幸です。このほかいろいろ括話し上げたいことはま だまだたくさんありますが，次の機会にゆずります。

本稿によつて，鉄骨構造がつくられている実態につい て理解を深めていただき，鉄骨構造の正しい普及発展に 対してょりいつそらの協力をいただきたいと思いま村。

\section{交献}

$1) R$. S. Kirby, $S$. Withington, $A . B$. Darling and $F$. G. KILGOUR: Engineering in History (1956) [McGraw-Hill Book Company]

2 ) $H$. Straub: A History of Civil Engineering, translated from the German "Die Geschichte der Bauingenieurkunst" (1949), English translation by $E$. Rockwell (1960) [Leonard Hill Limited]

3 ) 中沢護人：鋼の時代（1964）[岩波書店]

4 ) 成瀬勝武：橋 (1941) [河出書房]

5 ) G. Roisecco: L'Architettura Del Ferro, Bulzoni Editore (1972)

6 ) 鋼材俱楽部：日本の鋼構造，6中野電々ビル (1977)

7 ) 鋼材俱楽部：日本の鋼構造，3 日本航空成田第一 ハンガー $(1975)$

8 ) R. Hammond: Engineering Structural Failures (i956) [Odhams Press Limited]

9 ) 日本鋼構造協会, 経済委員会: 84 年度鋼構造物 需要見通 L，JSSC. 1984. 7.

10）鋼構造ジャーナル，No. 147 (1984)，No. 149 (1984)

11）日本経済新聞：安值に摇九る鉄骨，（ト），（下） (昭和 59 年 7 月 27 日, 28 日)

12）山崎徳也，滰沢章三：日本建築学会論父報告集 (1977) 252, p. 23

13）藤本盛久，佐藤亘広，松榢展門：日本建築学会論 文報告集（1976）245，p. $75 ，(1978) 264 ，$ p. 73 ， (1979) 275 , p. 1, (1979) 276 , p. 27

14）日本鋼構造協会関西地区委員会：鋼構造物の欠陥 評価之安全性, JSSC, Vol. 12 (1976) 124, p. 27

15）藤本盛久，松下真治：日本建築学会論文報告集 (1981) 301 , p. 53

16) 藤本盛久, 佐滕 誠, 佐滕亘宏, 松本正巳, 滕盛 紀明，中边照幸，松塚展門，磯田和彦，打越瑞 昌: 日本建筑学会大会学術講演梗概集 (1978), p. 1255 , p. 1257

17）日本建築学会：鋼構造建築溶接部の超音波探傷検 查規準

18）仲 威雄：溶接学会誌，24 (1955) 7, p. 20; 溶接 学会誌, 24 (1955) 11, p. 17

19）藤本盛久，松下真治：日本建築学会論文集 (1981) 309, p. 41

20）鋼材俱楽部：地震・強風・豪雪に上る鉄骨構造の 被害と設計・施工の手引き(1980)

21）日本溶接協会：耐ラィラテア鋼材の特性，WES 3008-1981 (1981) 
22) 藤本盛久：第 56 问西山記念技術講㭫（日本鉄鋼 協会編）(1978)，p. 69

23 ) 滕本盛久: 第 98 -99 回西的念技術講座（日本 鉄鋼協会編）(1984)，p. 37

24) 建材試験センター:「構造材料の安全に関する調 査研究」研究報告書, 昭和 48 年度 昭和 57 年 度

25）滕本盛久, 金鐘洛, 中込忠琞, 松村弘道, 多賀 雅泰: 日本建築学会大会学術講演梗概集 (1982), p. 1775 , p. 1777

26) 藤本盛久, 中込忠男, 橋本篤秀, 泉満, 松村 弘道, 松下真治, 金鐘深, 大畑次郎: 日本建築学 会大会学術講演梗概集 (1983)， p. 1273，p. 1775, p. 1277
27）沼崎吉次：普通鋼電炉, No. 33 (1982), p. 1

28) 藤本盛久, 矢部喜堂, 滕盛紀明, 中込忠男: 日本 建築学会論文報告集 (1983) 334, p. 47

29) 鋼材クラブ：H形鋼構造標準接合部 N (1980)

30) 藤本盛久：構造工学の基礎, エンジニヤリングサ イェンス講座 27 (1980) [共立出版]

31) 藤本盛久: 鋼構造学の発展, カラム No. 15 (1965), p. 23

32) 藤本盛久: 自然と建築構造, 構造工学研究 (1968) [東京大学出版会]

33) 藤本盛久: 日本建築学会大会学術講演梗概集 (1984), p. 1481

34) 藤本盛久, 憍本篤秀, 中込忠男, 山本美佐夫：日 本建築学会大会学術講演梗概集 (1984), p. 1483 